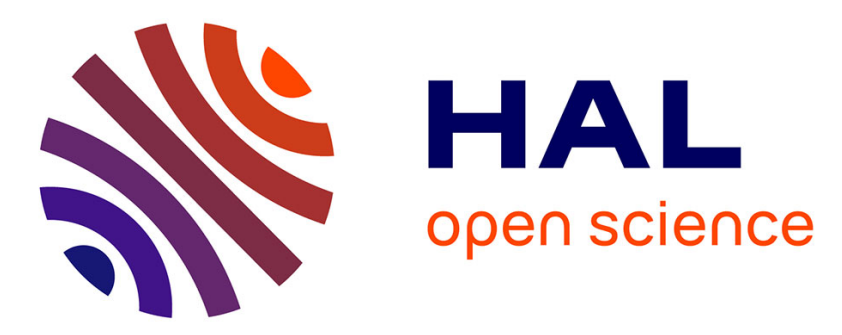

\title{
Project leaders as team boundary spanners: Relational antecedents and performance outcomes
}

Sébastien Brion, Vincent Chauvet, Barthelemy Chollet, Caroline Danièle

Mothe

\section{To cite this version:}

Sébastien Brion, Vincent Chauvet, Barthelemy Chollet, Caroline Danièle Mothe. Project leaders as team boundary spanners: Relational antecedents and performance outcomes. International Journal of Project Management, 2012, 30 (6), pp.708-722. 10.1016/j.ijproman.2012.01.001 . hal-00919228v2

\section{HAL Id: hal-00919228 \\ https://hal.science/hal-00919228v2}

Submitted on 28 Jan 2014

HAL is a multi-disciplinary open access archive for the deposit and dissemination of scientific research documents, whether they are published or not. The documents may come from teaching and research institutions in France or abroad, or from public or private research centers.
L'archive ouverte pluridisciplinaire HAL, est destinée au dépôt et à la diffusion de documents scientifiques de niveau recherche, publiés ou non, émanant des établissements d'enseignement et de recherche français ou étrangers, des laboratoires publics ou privés. 


\title{
NPD Project leaders as team boundary spanners: Relational antecedents and performance outcomes
}

\author{
S. Brion, V. Chauvet, B. Chollet, C. Mothe
}

\section{Introduction}

The specific contribution of team leaders to the performance of NPD projects has been widely studied in the project management literature (Aronson et al., 2008; Sarin and O'Connor, 2009). Due to their pivotal role in coordination, planning, conflict solving, and many other important aspects of project management, project leaders' professional qualifications and leadership style make a difference (Odusami et al. 2003). Beyond these team-oriented leadership roles, project leaders also bring value through their ability to manage key relationships outside the team. Indeed, project performance is highly dependent on access to external technical inputs, coordination with important stakeholders, and support from top management and other players who influence the project without belonging to the project team (Ancona and Caldwell, 1992; Choi, 2002).

Tushman and Katz (1980) referred to this aspect of the project leader's role as "boundary spanning". Recent research into team management has revived this notion (Marrone et al., 2007; Faraj and Yan, 2009; Joshi et al., 2009; Ratcheva, 2009; Marrone, 2010), and clarified the overall impact of boundary spanning on team performance. Nevertheless, some questions of particular importance for NPD project management remain unanswered. For instance, what types of boundary-spanning activities have the greatest impact on project performance and do they all bring value? To date, research has concentrated either on one type of boundary spanning activity, for example, searching for external knowledge (Ratcheva 2009), or considered boundary spanning as a single activity with no distinction between different types of activity. Our research was designed to try and fill this gap by developing the notion that not all boundaryspanning activities are beneficial. For example, focusing on relations with external players may consume a lot of time and energy and reduce the project leader's focus, thereby negatively impacting end-performance. Overall, greater understanding is needed 
of the range of objectives boundary-spanning activities can reach. This question is particularly challenging in the context of new product development, as this is usually a highly complex processes that may involve several boundary spanning roles, such as combining knowledge that can be spread across a number of players (Sheremata, 2000; Marrone, 2010), coordinating with stakeholders, and lobbying for top management support, all of which take place in a context of internal competition for resources and managerial attention (Joshi et al., 2009).

Applying the notion of boundary spanning to the work of NPD project leaders also raises the question of why some project leaders perform better than others in these activities. What do project leaders need to be good at this role? Although conceptual reviews have resulted in some propositions being put forward, little empirical research has been carried out on this topic (Marrone 2010). Some studies suggest that team leaders' abilities to handle these activities relate mostly to their "organizational influence", a notion that combines informal status and hierarchical power (Eisenhardt and Tabrizi, 1995; Tatikonda and Rosenthal, 2000). We suggest a complementary view in which boundary spanning is seen as being relational in nature; therefore, the form and composition of project leaders' personal networks of relationships may significantly impact their abilities to successfully perform their roles. Some leaders have social ties throughout their organization, or even across firm boundaries, that provide easy and direct pathways to technical help and other types of support, whereas other leaders have less valuable social ties and therefore end up struggling against the organizational context or wasting time locating sources for ideas and resources.

To conceptualize these network level antecedents, we follow a recent trend in project management literature (Kratzer et al. 2010; Di Vincenzo and Mascia 2011) by applying an approach that connects personal networks to performance on the individual or collective level (Burt, 1992; Seibert et al., 2001; Rodan and Galunic, 2004). By analyzing the impact of team leaders' personal networks on their effectiveness at boundary-spanning activities affecting performance, we investigate a traditional question, the sources of project leader performance (see for example Cheng et al. 2005, Fisher 2011), from a new angle. In particular, we stress that a leader's personal skills and background cannot be considered in isolation, as to be effective they must be associated with a suitable personal network. Our overall aim was to fill an important 
gap in the project management literature and to provide additional theoretical insights into NPD performance. Our research reveals a possible explanation why some project leaders are more efficient than others in their interactions with actors outside the team. To the best of our knowledge, our work is the first study to empirically test the role of a team leader's personal network in carrying out these boundary-spanning activities. As Joshi et al. (2009) noted following a survey of the literature on team boundary spanning, past research has only examined task-based, team-level and contextual antecedents. In addition to meeting the call for more empirical research on boundary-spanning activities (Ratcheva 2009, Marrone 2010), our research goes much further by suggesting that some boundary-spanning activities are not worth project leaders spending their time and energy on.

Through an on-line survey of project leaders at French firms developing innovative new products, we tested the impact of project leaders' boundary-spanning activities on NPD outcomes and explored the antecedents of these activities in terms of personal networks. We showed that some network characteristics have a positive impact on boundary-spanning activities, and identified which of these activities lead to higher NPD outcomes. In particular, "obtaining political support" and "scanning for information and ideas" are the boundary-spanning activities with the greatest impact on NPD performance. Furthermore, project leaders' effectiveness in these activities improves when their personal networks are characterized by strong ties and structural holes. Interestingly, a project leader's personal network also influences one other boundary activity, "protecting the team", but this activity does not impact NPD performance. Overall, our findings provide an integrative explanation for why some project leaders are better than others at boundary-spanning activities, thereby shedding new theoretical light on why team leaders' personal networks are important to NPD performance.

\section{Theoretical framework}

NPD project performance is strongly influenced by how teams use boundaryspanning activities to access resources that are external to the team (Ancona and Caldwell, 1992; Choi, 2002; Marrone et al., 2007; Faraj and Yan, 2009) (2.1.). We 
highlight the specific role of project leaders in these activities (2.2). Then, we adopt a social-network approach to investigate the role of project leaders' personal networks in their ability to pursue boundary-spanning activities (2.3).

\subsection{Team boundary spanning and NPD outcomes}

NPD teams work in a dynamic and uncertain environment and must face a high level of complexity when interacting with different units inside and outside the firm. The social context in which NPD projects are embedded is increasingly important, as many resources required for a project are located outside the team (Keller, 2001; Marrone et al., 2007; Ratcheva, 2009; Marrone, 2010). NPD teams have to undertake a range of activities (coordination, knowledge transfer, negotiation, lobbying, etc.). Moreover, firms increasingly adopt project-based structures when working on uncertain and complicated tasks linked to innovation. The embeddedness of projects in complex exchange processes involving internal and external boundary-spanning relationships is therefore increasingly predominant in NPD projects.

Although a vast body of research has focused on internal processes, boundaryspanning activities have received much less attention. Nevertheless, they have been identified as being critical for NPD projects (Ancona and Caldwell, 1992; Choi, 2002; Marrone et al., 2007; Edmonson and Nembhard, 2009; Sarin and O'Connor, 2009; Marrone, 2010). In keeping with prior work (e.g., Ancona, 1990; Ancona and Caldwell, 1992; Marrone et al., 2007; Faraj and Yan, 2009), we defined boundary spanning as "actions undertaken so as to establish linkages and to manage interactions with parties within the external environment" (Marrone, 2010, 914). Whereas several empirical studies have shown that a project team's success depends on the acquisition of sufficient resources, little attention has been paid to why some teams are more successful than others in obtaining these resources (e.g. Carbonell and Rodriguez-Escudero, 2009; Chen et al., 2010). Internal competition for resources between different projects occurs within an organization (Ancona and Caldwell, 1992). This competition puts additional pressure on teams - and especially on their leaders - to draw up an influence strategy rather than simply waiting for decisions to be handed down. This aspect underlines the complex 
dynamics of social exchanges between team members, their leaders and project stakeholders inside and outside the firm.

Ancona and Caldwell's (1992) article constitutes a valuable starting point as it provides relevant concepts to clarify the notion of boundary-spanning activities, and has served as a reference for the few subsequent empirical studies (Marrone et al., 2007; Faraj and Yan, 2009). After performing a factor analysis on 24 boundary-activity items, Ancona and Caldwell (1992) identified four types of activities: "ambassador" activities that include both protective and persuasive goals, "task coordinator" activities that are related to coordination and negotiation with outsiders and stakeholders, "scout" activities related to scanning, mapping and information gathering, and "guard" activities that are undertaken to avoid releasing information. In line with Ancona and Caldwell (1992) and Faraj and Yan (2009), we examined four boundary-spanning activities: political support, team protection, external coordination, and information scanning.

Obtaining political support is an essential aspect of NPDs, alongside careful coordination, technical abilities and market information (Dougherty and Hardy, 1996; McLoughlin et al., 2001). Teams involved in "ambassador" activities pursue two basic goals (Ancona and Caldwell, 1992; Dougherty and Hardy, 1996; McLoughlin et al., 2001; Marrone et al., 2007; Marrone, 2010). The first goal is to understand the political landscape, to accurately determine what top management's expectations are, and to differentiate between potential enemies and allies who will support initiatives. The second goal is to ensure the legitimacy of the project in a context of inter-team competition for budget and time resources. This involves promoting the project's strategic value in order to justify access to resources, keeping the organization informed, and reacting promptly to quell doubts expressed by boundary-spanning actors.

Protecting the team differs from boundary-spanning pressure and other ambassador activities (Faraj and Yan, 2009), most of which involve identifying potential supporters, locating resources and trying to obtain them. In contrast, protecting the team is a more defensive activity, as it involves playing a buffer role and managing trade-offs between necessary (to the team) and unnecessary boundary-spanning information, rather than "going out" to grab resources. In other words, some activities are oriented towards obtaining political support, whereas others are oriented towards protecting the team. 
Coordinating with external actors is a basic boundary-spanning activity that refers to interactions with important external (to the team) actors with whom the team works interdependently. For instance, it involves ensuring that outside contributors meet deadlines, understand expectations, and get feedback on product design and specifications, etc. The need for these activities is a direct correlate of the specific tasks the team has to complete in order to meet project goals. These activities may involve both vertical and horizontal interactions.

Scanning for ideas and information is crucial if a team is to propose original solutions, which are an essential element of NPD. Most importantly, a team must obtain accurate information about market needs and ideas, and about how to meet them. It then has to obtain the technical knowledge required to ensure the functional performance of a new-to-the-market product or a significantly improved existing product. Team leaders will only be able to benefit from boundary-spanning views and original ideas if they are capable of integrating disparate information and knowledge (Hansen et al., 2001; Reagans et al., 2004). In addition, a NPD project leader who relies entirely on internal information will probably lack the necessary resources to design a successful new product. Unlike coordinating with external actors, scanning for ideas and information entails interactions with people who are not necessarily project stakeholders.

Whereas the above-mentioned studies (Ancona and Caldwell, 1992; Marrone et al., 2007; Marrone, 2010) focus on the impact of boundary-spanning activities by any team member, our research focused on the specific contribution of project leaders, and takes a further step by considering that their effectiveness in this respect mediates the relation between network variables and NPD outcomes.

\subsection{Project leaders as boundary spanners}

A number of studies show that team leader characteristics explain a large part of NPD project end-performance (Jassawalla and Sashittal 2000; Sarin and McDermott 2003; Fisher 2011). Interestingly, many of these studies focused on behavioral aspects of leaders with respect to the team they manage (Odusami et al., 2003). At the same time, some researchers maintain that the ability to span different groups and relate the team to its environment is also a key aspect of team leadership (Balkundi and Kilduff, 2005). For example, Edmondson (2003) found that in highly multidisciplinary projects, 
boundary spanning is a crucial part of the project leader's role. Without a leader taking an active role in boundary spanning, "teams may make decisions that are inconsistent with other organization goals or constraints or fail to take advantage of available support or resources" (Edmondson 2003: 1423).

The importance of project leaders in the boundary-spanning process is due to the nature of their position. As well as regularly reporting to top management, project leaders personify the project to the rest of the organization (Joshi at al., 2009). Consequently, they play a pivotal role in resource flows and information circulation between the team and the rest of the organization. In addition to their formal position, project leaders often play an important role through their access to informal channels, which are important - if not crucial - sources of information about the organization, other on-going projects and all the "behind the scenes" activities that can impact a project (Bresnen et al., 2004). Similarly, research into the "organizational influence" of project leaders (Scott, 1997; Gerwin and Barrowman, 2002) has shown that the project leader's informal status significantly impacts NPD performance (Clark and Fujimoto, 1991; Eisenhardt and Tabrizi, 1995; Sarin and McDermott, 2003).

At the same time, it is not clear from the literature whether leading a project requires project leaders to personally undertake all four types of boundary-spanning activity noted above or whether they can delegate some of these activities to other team members. Thus, conceptualizing boundary-spanning as a fundamentally multifaceted activity paves the way for conducting empirical tests to pinpoint which activities are most important to a project leader's contribution. For example, research tends to support the notion that a project leader plays a crucial role in the "obtaining political support" activity. A project leader's influence and prestige can lead outsiders to perceive the project as worthwhile and thereby increase the chances of the project being successful (Scott, 1997; Sarin and McDermott, 2003). Influential project leaders can also more easily help their teams secure resources and support from top management (Eisenhardt and Tabrizi, 1995).

Similarly, the second boundary activity we outlined, "protecting the team", is a typical feature of project leadership. A common feature of project-based organization is that any team member can be subject to external demands, potentially reducing the commitment and energy that person devotes to the project (Faraj and Yan 2009). In 
such situations, the project leader is the only person capable of intervening and negotiating clear limits on the external demands that can be made on their team members (Jassawalla and Sashittal 2000). In addition, the project leader is often the person top management considers accountable when it comes to easing conflicts between team members and outsiders (Sarin and McDermott, 2003).

Project leaders may also play an essential role in the third boundary-spanning activity, "coordinating with external actors". Because the project leader is the most accountable member of the team, he or she must have close and regular contacts with the project's key stakeholders (Edmondson, 1999; 2003; Zaccaro et al. 2001). Furthermore, as the person in charge of managing and reviewing the project over time, the project leader usually has unique knowledge of the "big picture" and is therefore better placed than any other team member to influence discussions with other groups or to negotiate deadlines and budgetary constraints.

The final boundary spanning activity, "searching for information and ideas", is also a crucial dimension for NPD projects, as the goal of any NPD project team is to produce a structure that facilitates the integration of varied expertise and knowledge (Edmondson and Nembhard 2009). In order to nurture this process, knowledge and expertise has to be gathered within the project environment along the way. Consequently, this type of boundary spanning activity is much more task-centered than the other activities because it does not strictly deal with the project's management. As such, it may be perceived as falling outside the project leaders' remit. On the other hand, it could be argued that limited involvement of project leaders in this activity may adversely affect project outcomes because key decisions would then be based on an inaccurate understanding of the technical options available and would be taken without considering many potentially creative ideas (Nonaka, 1991).

Taken together, the arguments outlined in sections 2.1 and 2.2 suggest two complementary notions. First, the effectiveness of project leaders in boundary-spanning activities is an important aspect in NPD performance. Second, a thorough investigation of this explanatory influence is needed, as it is not clear which of the four activities a project leader should focus on in order to have the most positive influence on NPD project performance. These arguments led us to formulate the following hypothesis: 
P1: The more effective a project leader in boundary-spanning activities, the higher the NPD outcome

\subsection{Project leaders' personal networks as antecedents of boundary activities}

The importance of relationships for individual and organizational performance has received a great deal of attention (Granovetter, 2005). Some authors have referred to "embeddedness" to designate situations where organizational processes appear to be the result of social framing and exchanges through social ties (Uzzi, 1997; Granovetter, 2005; Rost, 2010). Others have used the concepts of social networks (Borgatti et al., 2009) or social capital (Adler and Kwon, 2002). Another stream of research has insisted on the effects of "small world" networks (Watts and Strogatz, 1998) on system dynamics (Uzzi and Spiro, 2005; Lazer and Friedman, 2007). In the present research, given the embeddedness of NPD projects within their social environment, it seemed particularly relevant to refer to social network theory to identify antecedents of boundary-spanning activities (Bresnen et al., 2004). Here we seek to better identify the relational aspects of NPD processes, considering that a team leader's ability to perform boundary-spanning activities depends on his/her personal network.

Research has shown that personal networks are useful for reaching both personal (early promotion, job hunting, etc.) and organizational goals (Burt, 1992; Lin, 1999; Seibert et al., 2001; Rodan and Galunic, 2004). A team's network, through the leverage of boundary-spanning resources, helps it to be effective (Collins and Clark, 2003; Cross and Cummings, 2004; Balkundi and Harrison, 2006). Studies of innovation teams (Hansen et al., 2001; Reagans et al., 2004) have shown that relationships between team members and other individuals that are internal or external to the firm increase the chances of project success. Tiwana (2008) showed that some characteristics of team members' personal networks help them to innovate. More specifically, bridging ties provide access to a range of capabilities, whereas strong ties complement bridging ties in facilitating the integration of knowledge into the project. Research into the role of boundary-spanning activities in organizational and team performance (Katz and Tushman, 1981; Marrone et al., 2007) has also indicated that the network's effect on team performance is due to the fact that it provides team leaders with access to resources. However, none of these studies tested these impacts and therefore they did 
not determine which ones are critical to project success. The authors only tested simple models in which networks were directly related to performance.

As a result, these contributions leave a number of questions unanswered, including that of the types of resources that networks bring project leaders, and which actions, critical for success, are facilitated through the networks. Answers to these questions become clearer when considering network dimensions and boundary-spanning activities as two parts of the same causal path. In fact, it could be argued that network variables have an indirect effect on NPD performance, with boundary-spanning activities playing a mediating role between personal networks and NPD outcomes (see Figure 1). The rationale underlying this argument is that a personal network does not provide benefits by itself. Rather, it makes it easier for team leaders to perform boundary-spanning activities. Consequently, it is necessary to better understand how network variables impact these activities.

Our objective was to identify the types of networks that provided the highest benefits. First, we characterized the team leaders' networks, referring to Burt's (1992, 2004) extensive studies on the role of network structure, which led him to highlight the importance of structural holes, defined as the absence of a social tie between two alters in ego's network. The main argument is that having many structural holes in a network (i.e., having ties with unconnected others) places ego in an ideal position within the general flow of information. As unconnected alters have distinct information sources, they provide ego with a diversity of information and resources that may be valuable for the project.

Second, we assessed the strength of NPD team leaders' ties, assuming that weak ties and strong ties will not bring the same contributions. Indeed, the literature presents mixed findings. Granovetter (1973) pointed out the positive effect of weak ties on access to valuable and diverse information. However, weak ties have also been associated with failures in the circulation of specific types of information. For instance, some of the information required by team leaders may be unofficial and therefore not publicly available (Balkundi and Kilduff, 2005; Hochwarter et al., 2007). Acquiring such information may be facilitated through strong ties, which are often combined with high levels of trust, especially if the information in question is sensitive and if transferring it represents a risk for the provider. Moreover, the logic of strong ties 
between individuals assumes that there is a motivation for a contact to provide resources and support to a focal actor (Krackhardt, 1992). This aspect appears critical when taking into account the internal rivalry between projects. In such situations, team leaders with strong ties could be more apt at using them in order to acquire the resources and support required for their projects.

Third, we used two measures of bridging ties - vertical and horizontal bridging ties to assess the specific position of alters (i.e., people in ego's network) which is directly linked to the amount of resources ego may acquire through his/her network (Lin, 1999). Team leaders particularly need ties to people that offer connections to resources and information flows other than those that are available through their close environment (Oh et al., 2004). Ties should therefore span organizational boundaries, whether vertical or horizontal.

Based on Oh et al. (2004), we considered vertical bridging ties as being personal relationships established with alters at higher levels. These connections could be useful to bridge hierarchical boundaries and to bypass the classical line of authority that may impede project progress. These ties may be critical in order to obtain management support and to accelerate the allocation of resources, for instance. Horizontal bridging ties are defined as personal relationships with alters in other departments or organizations (Oh et al., 2004). This type of ties could be very useful in acquiring original information and spreading positive information about the project, which may result in better knowledge of the project inside and outside the organization, and thereby contribute to the project's positive reputation. We therefore propose that the characteristics of project leaders' personal networks may influence their effectiveness when engaging in boundary-spanning activities:

P2: The project leader's personal network will have a positive impact on its effectiveness in team boundary-spanning activities

Our theoretical development led us to the following framework (Figure 1), which assumes that the relationship between a project leader's personal network and NPD outcomes is mediated by four boundary-spanning activities.

\section{Insert Figure 1 here}

\section{Sample and measures}


The study was conducted on a sample of 73 project leaders in manufacturing firms (3.1.) and assessed the variables of NPD outcomes, boundary-spanning activities, network characteristics, and controls (3.2).

\subsection{Sample}

We used a sample of project leaders involved in NPD projects in a variety of industries. An on-line questionnaire was sent to 782 project leaders listed in two French databases: AFITEP (French Association of Project Management) and Rhône-Alpes Chamber of Commerce. The study used name generators, with respondents being asked to name contacts who played a role in their day-to-day professional activities. Project leaders were required to complete the questionnaire with reference to a completed NPD project. After two follow-ups, we obtained 243 responses, representing a high response rate of $31 \%$. To ensure that our study was based on a homogenous sample, we crossed the sector variable with the nature of the project variable (new product/service) and selected only those projects involved in NPD processes. This reduced the sample to 83 questionnaires. As 10 of these questionnaires were incomplete, our final sample consisted of 73 valid questionnaires for project leaders in the manufacturing sector. The relatively small size of the sample may reflect the difficulty of obtaining access to information about innovation projects, as these are often considered confidential. However, this pattern is consistent with previous studies addressing teams' boundaryspanning activities (Ancona and Caldwell, 1992; Marrone et al., 2007; Marrone, 2010).

Appendix 1 provides the main descriptive statistics. $61.6 \%$ of the firms had more than 500 employees, $61.7 \%$ of the projects took between 6 and 23 months, and $60.3 \%$ of project teams had between 1 and 5 members. The degree of innovation was considered to be quite high or high for $68.5 \%$ of the respondents, who were essentially male $(83.6 \%)$, had a master's degree $(84.9 \%)$ and were at an N-2 or N-3 hierarchical level $(69.8 \%)$

\subsection{Variables}

\subsubsection{NPD outcomes}


The issue of how NPD performance can be measured is still subject to intense debate (Hart et al., 2003). As a result, many researchers advocate the simultaneous use of several different dimensions (Hoegl and Gemuenden, 2001). A great majority of researches have used perceptual measures. In this study, we adopted this type of measure for three main reasons: the firms' reluctance to release actual financial data (Olson et al., 1995), managers' unwillingness to provide objective measures (Nakata and Im, 2010), and the need to standardize business outcomes across different industry settings (Olson et al., 1995). Furthermore, past studies have demonstrated a close correspondence between subjective and objective measures of performance (Song and Parry, 1997; Nakata and Im, 2010). As in Olson et al. (1995), our measures consisted of a series of single-item assessments by the project managers.

We measured NPD outcomes on two distinct dimensions. The first took into account the commercial and financial success of a new product, an aspect that is sometimes referred to as "boundary-spanning performance", as it defines NPD performance from the market point of view (see Garcia et al., 2008). Commercial and financial success refers to boundary spanning outcomes in terms of economic and market performance of a new product. This type of project outcome, here called "external performance", was measured (see Appendix 2) with items adapted from previous studies that adopted a similar approach to performance measurement (Griffin and Page, 1993; Garcia et al., 2008). The second dimension is related to longer-term outcomes, such as the acquisition of new knowledge, as research has shown that firms must take into account long-term outcomes and not only market success (Denison et al., 1996; Hoegl and Gemuenden, 2001). The amount of knowledge acquisition resulting from the project is an important dimension of NPD performance because it can strengthen a firms' ability to innovate in the future. We adopted a similar approach to Denison et al. (1996) and Hoegl and Gemuenden (2001), taking into account the acquisition of both managerial and technical knowledge. All items referring to outcomes were measured using 4-point Likert scales (see Appendix 2).

\subsubsection{Team boundary-spanning activities}

The four boundary-spanning activity measures (coordinating with external actors, scanning for ideas and information, obtaining political support and protecting the team) 
were based on previous research (Ancona and Caldwell, 1992; Faraj and Yan, 2009). Appendix 2 shows the measures and their sources. All items referring to boundaryspanning activities were assessed using 6-point Likert scales. As expected, construct reliability indicators (Table 1) showed that each of these item categories fits well with their theoretically related constructs.

\subsubsection{Network variables}

The questionnaire asked respondents to list their contacts (name-generators), and then to answer single-item questions about each contact (name interpreters). The questions respondents had to answer in order to provide a list of contacts were: "List the contacts that are important sources of advice in your work"; "List the contacts that are important information sources for you concerning your organization" and "List the contacts whose endorsement and/or support are important for your initiatives". The measures used for each respondent were indices calculated by aggregating responses for all the contacts listed in the name-generators.

\section{Structure of the network: structural holes}

The number of structural holes (Burt, 1992, 2004) in the leaders' networks was measured in terms of aggregate constraint (Burt 1992), which "is a function of the network's size, density, and hierarchy (networks in which all contacts are exclusively tied to a dominant contact) and is designed to measure the extent to which the focal actor's network lacks structural holes" (Xiao and Tsui, 2007: 14). Respondents had to indicate if their contacts knew each other (close vs. not close). Formally, this is defined as (Burt, 1992):

$$
c_{i j}=\left(p_{i j}+\sum_{q} p_{i q} p_{q j}\right)^{2}, \quad q \neq i, j
$$

where $\mathrm{p}_{\mathrm{ij}}$ is the proportion of $\mathrm{i}$ 's relations invested in contact $\mathrm{j}$, and $\Sigma_{\mathrm{q}} \mathrm{p}_{\mathrm{iq}} \mathrm{p}_{\mathrm{qj}}$ is the portion of $i$ 's relations invested in contact $q$ who are in turn invested in contact $\mathrm{j}$. Considering dichotomous ties between every pair of alters (i.e., with only two options: a tie exists or does not exist. The intensity of ties is not considered), $p_{i j}$ equals $1 / n$, where $n$ is the number of alters in the network. Applying a similar logic to $\mathrm{p}_{\mathrm{iq}}$, results in the following simplified definition of aggregate constraint:

$$
c_{i j}=\left(\frac{1}{n}\left(1+\sum_{q} p_{q j}\right)\right)^{2}, \quad q \neq i, j
$$


An ego's network constraint measure is the sum of all the alters' individual constraints:

$$
c_{i}=\sum_{j} c_{i j}, \quad i \neq j
$$

The value of $p$ was obtained by asking each respondent to indicate whether a pair of contacts was connected, and to repeat this for every pair of contacts. Aggregate constraints for every respondent were calculated from this data using UCINET VI (Borgatti et al., 2002). The higher the project leader's constraint score, the lower the number of structural holes in his/her network. However, in order to make interpretation easier, we used a similar procedure to Xiao and Tsui (2007) and computed the variable structural holes as (1 - aggregate constraint).

Strength of ties

Although the concept of tie strength is widely used in the literature, it has been measured in very different ways. Following Marsden and Campbell's arguments (1984), we chose a measure based on emotional closeness. For each alter cited in the name generators, the respondent was asked to assess the level of perceived emotional closeness (on a 4-point Likert scale from "not close at all" to "very close", based on Burt 1992). The strength of each respondent's ties was the average closeness for all the contacts he/she listed.

\section{Vertical and horizontal bridging ties}

Concerning vertical bridging ties, each respondent was asked to assess the hierarchical level of each contact (5-point Likert scale from "no one under his/her responsibility" to "more than three levels of responsibility under him/her"). Hence we calculated the average hierarchical level for every contact. Respondents were also asked to state their own hierarchical level, using the same scale. We calculated a vertical bridging ties value for each respondent by taking the average hierarchical level of his/her alters minus his/her own level. A negative value for this variable indicated that the respondent's contacts were all at lower levels than the respondent. A high positive value indicated that the respondent's contacts were mostly at higher levels than the respondent. A value of 0 indicated that a respondent's ties were with people on a similar hierarchical level.

For horizontal bridging ties, respondents were asked to assess the relative position of each contact with respect to their own organizational unit. This was done using a 5-point scale: "same team", "same department", "elsewhere in the 
organization", "in a partner organization", "in another organization with no connection to mine". The average of the scores for all listed contacts was calculated to give a horizontal bridging ties value for each respondent.

\subsubsection{Control variables}

We selected a group of variables designed to capture project and respondent characteristics: project duration, team size and project leader's hierarchical level. Project duration was defined as the number of months team members worked together to complete the project (Sethi, 2000). Team size, a fixed resource that may influence individuals' abilities to carry out certain behaviors (Marrone et al., 1997) and thus to get certain resources, was defined as the number of people in the project team. The team leader's hierarchical position was an indication of the formal and informal status he/she enjoyed (Sarin and McDermott, 2003). The team leader's position is associated with his/her influence within the organization and helps increase his/her ability to achieve objectives. High-ranking leaders can thus improve a project's chances of success by ensuring that the NPD efforts are not limited by resource constraints (Brown and Eisenhardt, 1997). In line with this work, we hypothesized that a team leader with a high hierarchical level should have easier access to top management regardless of social network, thus gaining better support and information for the project. This was measured on a scale ranging from 5 for $\mathrm{N}$ : maximum level possible (CEO); 4 for $\mathrm{N}-1 ; 3$ for $\mathrm{N}-2 ; 2$ for N-3; 1 for other levels.

\section{Results}

Data analysis was conducted using the Partial Least Squares (PLS) method, a structural modeling technique that is well adapted to assessing predictive relationships (Wold, 1986). PLS can be used to model latent constructs, even under conditions of non-normality. It is particularly suitable for small- to medium-size samples (Chin et al., 1996). Our sample of 73 cases was large enough to carry out a PLS analysis, as it satisfies the heuristic condition that the sample size must be at least ten times larger than 
the largest number of structural paths directed at any one construct ${ }^{1}$. PLS analysis involves two stages: validating the measurement model, and assessing the explanatory and predictive power of the structural model.

\subsection{Measurement model results}

The measurement model was first examined for convergent and discriminant validity (Gefen and Straub, 2005). Convergent validity is demonstrated when items measuring a latent variable load with significant $t$-values on that construct. All items loaded significantly on their constructs, thus indicating adequate convergent validity ${ }^{2}$. Our model also showed convergent validity with average variance extracted: all constructs had an AVE above the recommended threshold of 0.5 (see Table 1).

\section{Insert Table 1 here}

Factor loadings and cross-loadings were used to examine discriminant validity, which is demonstrated when items strongly load on their theoretically assigned factors, and not on other factors. All constructs had loadings of above 0.6, without high cross loadings on the other constructs ${ }^{2}$. The square root of the AVE for any given construct was greater than the correlation between that construct and the other constructs in the analysis. Discriminant validity is shown in Appendix 3. Construct measures also showed adequate internal consistency (see Table 1). All composite reliabilities were above the recommended level of 0.7 (Nunnally, 1978). These analyses indicate adequate construct validity and reliability for the measures (see Table 1).

As the data collection process used in the present study could induce a commonmethod bias, remaining concerns about common-method bias (and single-informant bias) were addressed using a number of procedures and statistical tests recommended by Krishnan et al. (2006). One statistical remedy and two procedural remedies were introduced, thereby ruling out a number of common-method bias risks (see Appendix 4 for details).

\subsection{Structural model results}

\footnotetext{
1 The largest number of paths to any construct in the research model is 7 . This count includes the paths from the 3 control variables.

${ }^{2}$ All intermediary results are available upon request.
} 
Results for the tests of the structural model are shown in Figure 2. The structural model test included estimating the path coefficients and the explained variance. Figure 2 shows path coefficients and significance levels obtained through bootstrap ${ }^{3}$ sampling procedures for each path, plotted using solid black lines. $\mathrm{R}^{\mathbf{2}}$ values for dependent constructs ranged from 0.090 to 0.207 . Only two of the four network variables showed significant paths on boundary-spanning activities. Structural holes were positively linked with the capacity to protect the team $(\beta=0.292, \mathrm{t}=2.102, \mathrm{p}<0.05)$. The path from strength of ties to obtaining political support was positive and significant $(\beta=0.212$, $\mathrm{t}=1.922, \mathrm{p}<0.05)$, as was the path from strength of ties to scanning for ideas and information $(\beta=0.164, \mathrm{t}=1.725, \mathrm{p}<0.05)$. Vertical and horizontal bridging ties did not have any significant effects on boundary-spanning activities. In addition to these relationships, which partially support $\mathrm{P} 2$, we found significant links between boundaryspanning activities and NPD outcomes, in support of P1. Of the two NPD outcomes, commercial and financial success $(\beta=0.258, \mathrm{t}=1.713, \mathrm{p}<0.05)$ was significantly related to obtaining political support, and knowledge acquisition was linked with scanning for ideas and information and obtaining political support. More precisely, scanning for ideas and information was positively related to acquisition of technical knowledge $(\beta=0.242, \mathrm{t}=2.117, \mathrm{p}<0.05)$ and obtaining political support was positively related to acquisition of managerial knowledge $(\beta=0.282, \mathrm{t}=1.966, \mathrm{p}<0.05)$.

\section{Insert Figure 2 here}

Team size and project duration were not significantly related to boundary-spanning activities. Finally, hierarchical position of the project leader showed the only positive and significant path from a control variable to a boundary-spanning activity (to coordinate with boundary-spanning actors: $\beta=0.343, \mathrm{t}=1.821, \mathrm{p}<0.05)$.

\subsection{Mediation tests}

For strength of ties, Figure 2 shows three potential mediation effects: the first relates to the mediating effect of scanning for information and ideas when considering the relationship between strength of ties (measured via emotional closeness) and technological knowledge acquisition. The two others concern the mediating effect of obtaining political support when considering the relationship between, on the one hand,

\footnotetext{
${ }^{3}$ Sample size $=500$
} 
strength of ties and managerial knowledge acquisition and, on the other hand, strength of ties and NPD commercial and financial success. In order to establish mediation, the following conditions must hold (Judd and Kenny, 1981; Baron and Kenny, 1986):

- The independent variable must affect the mediator (in a first regression);

- The independent variable must affect the dependent variable (in a second regression);

- When regressing the independent variable and the mediator on the dependent variable, the mediator must affect the dependent variable (in a third regression);

- If the above conditions all hold in the predicted direction, then the effect of the independent variable on the dependent variable must be less in the third regression than in the second.

Full mediation holds if the independent variable has no effect in the third equation, whereas partial mediation is demonstrated when the effect of the independent variable on the dependent variable in the third equation is less significant than in the second equation. As can be seen in Table 2, only two of the three paths meet all the above-mentioned conditions. For information scanning, full mediation was obtained for strength of ties on technical knowledge acquisition. For political support, full mediation was obtained for strength of ties on NPD commercial and financial success, but we did not obtain any mediation effect for strength of ties on managerial knowledge acquisition.

\section{Insert Table 2 here}

For the two significant mediating paths, we performed a second test to determine whether or not the intervening variables carried the effects of the independent variable onto the dependent variable (Sobel, 1988). Sobel provided a significance test to control the indirect effects of an independent variable on the dependent variable via the mediator. Significant t-values indicate that the variables were important mediators. As shown in Table 2, this test was significant for the two paths involved.

\section{Discussion}

Past studies have shown that project leaders' actions drive NPD performance. Here we focus on boundary-spanning activities (Ancona and Caldwell, 1992; Marrone et al., 2007; Faraj and Yan, 2009; Joshi et al., 2009; Marrone, 2010) because, to the best of 
our knowledge, no research has explored the conditions that help project leaders be effective in performing these activities. Our results provide empirical support for the notion that NPD project performance is influenced by project leaders' effectiveness in key boundary-spanning activities (obtaining political support, protecting the team, coordinating with external actors, searching for information and ideas), and that this effectiveness depends, in turn, upon the project leader's personal network. More specifically, we report two important findings: "obtaining political support" has a much greater influence on project success than the other boundary-spanning activities, and success in these activities is greatly influenced by the value of the strong ties in the project leader's network. These findings shed new light on prior research in several ways.

First, we showed that project leaders do make a difference if they are effective at boundary spanning but that this happens mostly through two activities, not all four. Scanning for information and ideas and, above all, obtaining political support are the two main boundary-spanning activities that enhance NPD performance. Obtaining political support influences both knowledge acquisition, and commercial and financial success. These findings suggest that valuable projects can be hindered by a lack of political support, a factor that traditional project management tools and performance criteria do not take into account. From a theoretical point of view, they support the contention that the most critical roles of NPD project leaders are political in nature (Dougherty and Hardy, 1996; McLoughlin et al., 2001), a notion that is present in some theoretical models of project management (i.e., Actor Network Theory, see for example Markowsi, 2008) but that has so far received only limited attention.

The relative lack of attention paid to this question may be due to the predominance of what could be called the "rational approach to NPD", in which support, attention and resources are just project "inputs" that top managers modulate depending on a project's strategic value. However, our findings indicate a different reality in which support and resources are things project leaders have to obtain in the face of both intense internal competition and bounded rationality in decision processes. Lobbying for resources and support from key actors is therefore a crucial aspect of the role of NPD project leaders.

Although we found that a project leader's ability to "coordinate with external actors" does not impact performance, this does not necessarily mean that this type of 
boundary spanning is unimportant; it may just be that this role is better filled by other members of the team. An interesting research avenue would be to collect information from every member of project teams, as well as from project leaders, and compare the relative impacts of each member. This approach would allow various strategies to be evaluated. Some leaders may indeed adopt a fairly centralized approach where they are involved in all activities, whereas others may opt for a more shared approach in which boundary-spanning activities are distributed between all team members.

Second, we demonstrated that effectiveness in these activities is further improved when project leaders have a specific type of personal network. Two of the four network characteristics were found to have a positive impact (P2). Strong ties and structural holes had a positive impact on three boundary-spanning activities, two of which increased NPD performance, whereas horizontal and vertical bridging ties seemed to have no effect. We therefore provided preliminary responses to the related (but neglected) question of the antecedents of effectiveness in boundary-spanning activities. By highlighting the importance of strong ties for NPD projects, our findings also shed new light on the theoretical debate on the impact of weak ties vs. strong ties. In particular, strong ties lead to higher effectiveness when scanning for ideas and information, which in turn facilitates technical knowledge acquisition. Mediation tests show that scanning for ideas is a full mediator of strong ties on NPD performance. Strong ties also help the team obtain political support, which leads to increased boundary-spanning NPD performance as demonstrated by the full mediation effect. Some types of information require trust in order to be transferred, and trust does not easily develop through weak ties. In addition, weak ties do not allow the transfer of complex knowledge to the team (Hansen, 1999; Hansen et al., 2001), whereas strong ties facilitate the development of a common language and mutual understanding.

We contribute to the literature on the relative importance of strong and weak ties by showing that leaders' strong ties are likely to be much more valuable for NPD performance than weak ties. This interesting finding adds to extensive research on network characteristics and innovation, highlighting the critical role of project leaders' strong ties. However, this result contradicts other studies that have underlined the importance of weak ties, especially for NPD performance (Hansen et al., 2001; Reagans et al., 2004). These apparently contradictory results may be due to the curvilinear 
relationship between connectivity and group performance, demonstrated by Lazer and Friedman (2007: 686) in a study that showed that managing networks entails a trade-off between information diffusion (favored by strong ties) and information diversity (favored by weak ties), with the former enhancing a system's short-term performance, and the latter increasing its long-term performance.

\section{Conclusion, limitations and avenues for further research}

The aim of the present research was to improve our understanding of the factors that drive NPD performance, and especially the influence of the project leader's personal network, a subject that remains poorly studied (Turner, 2010). In line with Sence (2003), who analyzed the political issues impacting individual learning for project leaders during an innovation project, we emphasized the importance of political activities for NPD performance. We demonstrated that team leaders' personal networks have a positive impact on boundary-spanning activities, thereby enhancing NPD project performance. We found that when NPD project leaders engage in relational activities external to the team, they acquire new knowledge and increase the project's market success. These results are in line with those of Ancona and Caldwell (1992) and Faraj and Yan (2009).

Our study makes two main contributions to project management research. First, it shows that some boundary-spanning activities (especially political support) have a greater impact on performance than others. Second, by identifying key antecedents pertaining to social networks, we provide preliminary answers to a number of questions related to why efficient boundary-spanning relationships lead to improved performance. By showing that project leaders' personal networks (and, above all, strong ties) contribute to enhanced effectiveness in boundary-spanning activities, our focus on relational and political mechanisms allowed us to develop a coherent view of how NPD projects develop.

A number of major recommendations can be derived from these results. First, a logical conclusion of our findings is that firms should help project leaders develop their personal networks, as these networks facilitate boundary-spanning activities. This 
would help reduce the number of NPD projects that fail, especially in the case of boundary-spanning-oriented and complex projects with multiple stakeholders (Marrone et al., 2007; Ratcheva, 2009). However, the question of how networks can be modified through managerial action remains unanswered and is still subject to intense debate. Our results could also be taken to suggest that firms should choose project leaders on the basis of their pre-existing social networks, and not only on their managerial and technical skills. Second, our findings also impact human resources management. Our data highlight the importance of the quality of relationships for NPD team leaders, with strong ties having a positive impact on two critical boundary-spanning activities. Strong ties facilitate the acquisition of valuable knowledge and unofficial and sensitive information (Hochwarter et al., 2007) that requires trust in order to be transferred. Strong ties may also lead to additional resources, to better support for the project, to spreading positive information about the project, and to securing priority over other projects, especially in the case of direct ties with decision-makers. Third, project managers should be aware that their boundary-spanning activities may have considerable influence on the different dimensions of NPD performance (knowledge acquisition and new product success). This is all the more important as project managers, who often come from technical backgrounds, carry out these boundaryspanning activities "instinctively", or do not consider them at all, as they are not "directly" related to the project. Fourth, when project managers consider investing time in boundary-spanning activities, they have to concentrate on obtaining political support, thus developing strong ties with the firm's top management. Finally, project managers should be aware that their personal network directly impacts these boundary-spanning activities, especially when they include structural holes and strong ties.

The present study is not without limitations. Due to the sampling method used, there was a risk of common-method bias, which we minimized by using the control methods recommended by Krishnan et al. (2006). In addition, our study concentrated on small teams and on the role project leaders (and their personal networks) play in boundaryspanning activities. One way of addressing this problem would be to consider the personal networks of each project member (in addition to that of the project leader), as boundary-spanning activities are not the prerogative of project leaders, alone, especially in larger teams. Developing insights into the impact of team members' personal 
networks on boundary-spanning activities could improve project management in two ways. Firstly, it would help organizations define the composition of the team (depending on the quantity and type of boundary-spanning information needed for the project). Secondly, it would help determine the balance of attributes (geographical, emotional, professional proximities, etc.) a team leaders' personal network should include, given the characteristics of the project.

Because the small size of our sample prevents extended empirical generalizations being drawn from our study, further research involving larger samples is needed to fully validate our results. Nevertheless, despite the high number of variables and items, the sample was large enough for the purposes of this research, and by applying a statistical tool (PLS) that is appropriate for small samples (Chin et al., 1996), we were able to obtain statistically significant results. Lastly, this research indicates a critical link between project leaders' personal networks and two boundary-spanning activities. It would be interesting to further explore the role of other characteristics of project leaders, such as their personality traits. The link between project management and personal networks is indeed an exciting area for future research.

\section{REFERENCES}

Adler, P.S., Kwon, S.W., 2002. Social capital: prospects for a new concept. Academy of Management Review, 27(1), 17-40.

Aldrich, H., \& Herker, D. 1977. Boundary Spanning roles and Organization Structure. Academy Of Management Review, 2(2), 217-230.

Ancona, D., 1990. Outward bound: strategic for team survival in an organization. Academy of Management Journal 33(2), 334-365.

Ancona, D.G., Caldwell, D.F., 1992. Bridging the boundary: external activities and performance in organizational teams. Administrative Science Quarterly 37, 634-665.

Aronson, Z. H., Reilly, R. R., Lynn, G.S., 2008. The role of leader personality in new product development success: an examination of teams developing radical and incremental innovations. International Journal of Technology Management 44 (1/2), 5-27.

Balkundi, P., Kilduff, M., 2005. The ties that lead: A social network approach to leadership. The Leadership Quarterly 16, 941-961.

Balkundi, P., Harrison, D.A., 2006. Ties, leaders, and time in teams: Strong inference about network structure's effects on team viability and performance. Academy of Management Journal 49(1), 49-68.

Baron, R.M., Kenny, D.A., 1986. The moderator-mediator variable distinction in social psychological research: Conceptual, strategic and statistical considerations. Journal of Personality and Social Psychology 51(6), 1173-1182.

Borgatti, S.P., Everett, M.G., Freeman, L.C., 2002. Ucinet for windows: software for social networks analysis. Harvard, MA: Analytic Technologies.

Borgatti, S.P., Mehra, A., Brass, D.J. and Labianca, G., 2009. Network Analysis in the Social Sciences. Science February 13th, 892-895. 
Bresnen, M., Goussevskaia, A. \& Swan, J. 2004. 'Embedding new management knowledge in project-based organizations', Organization Studies, 25, 9, 1535-1555.

Brown, S.L., Eisenhardt, K.M., 1997. The art of continuous change: Linking complexity theory and time-paced evolution in relentlessly shifting organizations. Administrative Science Quarterly 42, 1-34.

Burt, R.S., 1992. Structural holes, the social structure of competition. Harvard University Press, Cambridge

Burt, R.S., 2004. Structural holes and good ideas. American Journal of Sociology 110: 349-399.

Carbonell, P., Rodriguez-Escudero A., 2009. Relationships among team's organizational context, innovation speed, and technological uncertainty: An empirical analysis. Journal of Engineering and Technology Management 26(1-2), 28-45.

Chen, J., Damanpour, F., Reilly, R., 2010. Understanding antecedents of new product development speed: A meta-analysis. Journal of Operations Management 28(1), 17-33.

Cheng, M.I., Dainty, A.R., Moore, D., 2005. What makes a good project manager? Human Resource Management Journal 15(1), 25-37.

Chin, W. W., Marcolin, B. L., Newsted, P. R., 1996. A partial least squares latent variable modeling approach for measuring interaction effects, in DeGross J.I., Srinivasan A. and Jarvenpaa S.L. (Eds.), Proceedings of the Seventeenth International Conference on Information Systems, Cleveland, $\mathrm{OH}$.

Choi, J. N., 2002. External activities and team effectiveness: Review and theoretical development. Small Group Research 33, 181-208.

Clark, K. B. et T. Fujimoto, 1991. Product development performance, Boston: Harvard Business School Press.

Collins, C.J., Clark, K.D., 2003. Strategic human resource practices, top management team social networks, and firm performance: the role of human resource practices in creating organizational competitive advantage. Academy of Management Journal 46(6), 740-751.

Cross, R., \& Cummings, J. N. 2004. Tie and Network Correlates of Individual Performance in Knowledge-Intensive Work. Academy of Management Journal, 47(6), 928-937.

Denison, D.R., Hart, S.L., Kahn, J.A., 1996. From chimneys to cross-functional teams: Developing and validating a diagnostic model. Academy of Management Journal 39(4), 1005-1022.

Di Vincenzo, F., Mascia, D., 2011. Social capital in project-based organizations: Its role, structure, and impact on project performance. International Journal of Project Management, in press.

Dougherty, D., Hardy, C., 1996. Sustained product innovation in large, mature organizations: overcoming innovation-to-organization problems. Academy of Management Journal 39(5), 1120-1153.

Edmondson, A.C., Nembhard, I.M., 2009. Product Development and Learning in Project Teams: The Challenges Are the Benefits. Journal of Product Innovation Management 26, $123-138$

Eisenhardt, K.M., Tabrizi, B.N., 1995. Accelerating adapative processes: Product innovation in the global computer industry. Administrative Science Quarterly 40(1), 84- 110.

Faraj, S., Yan, A., 2009. Boundary Work in Knowledge Teams. Journal of Applied Psychology 94(3), 604-617.

Fisher, Eddie. 2011. "What practitioners consider to be the skills and behaviours of an effective people project manager." International Journal Of Project Management 29, no. 8: 994-1002.

Garcia, N., Sanzo, M.J., Trespalacios, J.A., 2008. New product internal performance and market performance: Evidence from Spanish firms regarding the role of trust, interfunctional integration, and innovation type. Technovation, 28 (11), 713-725.

Gefen, D., Straub, D., 2005. A practical guide of factorial validity using PLS Graph: tutorial and annotated examples. Association of Information Systems 16, 91-109.

Gerwin, D., Barrowman, N.J., 2002. An evaluation of Research on Integrated Product Development. Management Science 48(7), 938-953. 
Granovetter, M., 1973. The strength of weak ties. American Journal of Sociology 78(6), 13601380.

Granovetter, M., 2005. The Impact of Social Structure on Economic Outcomes. Journal of Economic Perspectives 19(1), 33-50.

Griffin, A., Page, A.L., 1993. An interim report on measuring product development success and failure. Journal of Product Innovation Management 10, 291-308.

Hansen, M.T., 1999. The search transfer problem: The role of weak ties in sharing knowledge across organizational sub-units. Administrative Science Quarterly 44, 82-111.

Hansen, M. T., Podolny, J. M., Pfeffer, J., 2001. So many ties, so little time: A task contingency perspective on corporate social capital. Research in the Sociology of Organizations 8, 2157.

Hart, S., Jan Hultink, E., Tzokas, N., Commandeur, H.R., 2003. Industrial Companies' Evaluation Criteria in New Product Development Gates. Journal of Product Innovation Management 20(1), 22-36.

Hochwarter, W., Ferris, G., Zinko, R., Arnell, B., \& James, M. 2007. Reputation as a Moderator of Political Behavior-Work Outcomes Relationships: A Two-Study Investigation With Convergent Results. Journal of Applied Psychology, 92(2), 567-576.

Hoegl, M., Gemuenden, H.G., 2001. Teamwork quality and the success innovative projects: Theoretical and empirical evidence. Organization Science 12(4), 435-449.

Jassawalla, A. R., \& Sashittal, H. C. 2000. Strategies of Effective New Product Team Leaders. California Management Review, 42(2), 34-51.

Joshi, A., Pandey, N., Han, G., 2009. Bracketing team boundary spanning: An examination of task-based, team-level, and contextual antecedents. Journal of Organizational Behavior 30(6), 731-759.

Judd, C.M., Kenny, D.A., 1981. Process analysis: Estimating mediation in treatment evaluations. Evaluation Review 5, 602-619.

Katz, R., Tushman, M., 1981. An investigation into the managerial roles and career paths of gatekeepers and project supervisors in a major R\&D facility. R\&D Management 11, 103110.

Keller, R.T., 2001. Cross-functional project groups in research and new product development: diversity, communications, job stress and outcomes. Academy of Management Journal 44(3), 547-556.

Krackhardt, D, 1992. The Strength of Strong Ties: The Importance of Philos in Organizations." In N. Nohria \& R. Eccles (eds.), Networks and Organizations: Structure, Form, and Action: 216/239. Boston, MA: Harvard Business School Press.

Kratzer, J., Leenders, R. J., \& Van Engelen, J. L. 2010. The social network among engineering design teams and their creativity: A case study among teams in two product development programs. International Journal Of Project Management, 28(5), 428-436.

Krishnan, R., Martin, X., Noorderhaven N.G., 2006. When does trust matter to alliance performance? Academy of Management Journal 49(5), 894-917.

Lazer, D., Friedman, A., 2007. The network structure of exploration and exploitation. Administrative Science Quarterly 52, 667-694.

Lin, N., 1999. Social networks and status attainment. Annual Review of Sociology 25, 467-487.

Markowski K. 2008. Actor network theory for project management: use it or bin it?, Proceedings of the 22nd IPMA World Congress.

Mardsen, P., Campbell, C., 1984. Measuring tie strength. Social Forces 63(2), 482-501.

Marrone, J.E., Tesluk, P.E., Carson, J.B., 2007. A multilevel investigation of antecedents and consequences of team member boundary-spanning behaviour. Academy of Management Journal 50(6), 1423-1439.

Marrone, J. A., 2010. Team Boundary Spanning: A Multilevel Review of Past Research and Proposals for the Future. Journal of Management 36(4), 911-940. 
McLoughlin, I., Koch C., Dickson K., 2001. What's this “Tosh"?: Innovation networks and new product development as a political process. International Journal of Innovation Management 5(3), 275-298.

Nakata, C., Im S., 2010. Spurring cross-functional integration for higher new product performance: A group effectiveness perspective. Journal of Product Innovation Management 27(4), 554-571.

Nunnally, J.C., 1978. Psychometric Theory. McGraw Hill, New York.

Oakley, P. 1996. High-tech NPD success through faster overseas launch. European Journal of Marketing 30(8), 75-91.

Odusami, K.T., Iyagba, R.R.O., Omirin, M.M., 2003. The relationship between project leadership, team composition and construction project performance in Nigeria, International Journal of Project Management 21, 519-527.

Oh, H., Chung, M.-H., Labianca, G., 2004. Group social capital and group effectiveness: the role of informal socializing ties. Academy of Management Journal 47(6), 860-875.

Olson, E.M., Walker Jr., O.C., Ruekert, R.W., 1995. Organizing for effective new product development: the moderating role of product innovativeness. Journal of Marketing 59, 4862.

Podsakoff, P.M., MacKenzie, S.B., 2003. Common Method Biases in Behavioral Research: A Critical Review of the Literature and Recommended Remedies. Journal of Applied Psychology 88(5), 879-903.

Ratcheva, V., 2009. Integrating diverse knowledge through boundary spanning processes - The case of multidisciplinary project teams. International Journal of Project Management 27(3), 206-215.

Reagans, R., Zuckerman, E.W., McEvily, B., 2004. How to make the team: social networks vs. demography as criteria for designing effective teams. Administrative Science Quarterly 49(1), 101-133.

Rodan, S., Galunic, C., 2004. More than network structure: how knowledge heterogeneity influences managerial performance and innovativeness. Strategic Management Journal 25(6), 541-562.

Rost, K., 2010. The strength of strong ties in the creation of innovation. Research Policy 40(4), 588-604.

Sarin, S., \& Mac Dermott, C. 2003. The effect of team leader characteristics on learning, knowledge application, and performance of cross-functional new product development teams. Decision Science, 34(4), 707-739.

Sarin, S., O'Connor, G. C., 2009. First among Equals: The Effect of Team Leader Characteristics on the Internal Dynamics of Cross-Functional Product Development Teams. Journal of Product Innovation Management 26(2), 188-205.

Scott, S., 1997. Social identification effects in product and process development teams. Journal of Engineering and Technology Management 14(2), 97-127.

Seibert, S.E., Kraimer, M.L., Liden, R.C., 2001. A social capital theory of career success. Academy of Management Journal 44(2), 219-237.

Sense, A.J., 2003. A model of the politics of project leader learning, International Journal of Project Management 21, 107-114.

Sethi, R. 2000. Superordinate identity in cross-functional product development teams: its antecedents and effect on new product performance. Journal of the Academy of Marketing Science, 28(3), 330-344.

Sheremata, W.A., 2000. Centrifugal and centripetal forces in radical new product development under time pressure. Academy of Management Review 25(2), 389-408.

Sobel, M.E., 1988. Direct and indirect effect in linear structural equation models, in J.S. Long (Ed.) Common problems/proper solutions: Avoiding error in quantitative research, BeverlyHills, CA, Sage.

Song, X.M., \& Parry, M.E. 1997. A cross-national comparative study of new product development processes: Japan and the United States. Journal of Marketing, 61, 1-18. 
Tatikonda, M., Rosenthal, S., 2000. Successful execution of product development projects: Balancing firmness and flexibility in the innovation process. Journal of Operations Management 18(4), 401-425.

Tiwana, A., 2008. Do bridging ties complement strong ties ? An empirical examiniation of alliance ambidexterity. Strategic Management Journal 29(3), 251-272.

Tourangeau, R., Rips, L.J., Rasinski, K., 2000. The psychology of survey response. Cambridge, UK, Cambridge University Press.

Turner, J.R., 2010. Evolution of project management research as evidenced by papers published in the International Journal of Project Management, International Journal of Project Management 26, 1-6.

Tushman, M. L., Katz, R., 1980. External communication and project performance: an investigation into the role of gatekeepers. Management Science 26(11), 1071-1082.

Uzzi, B., 1997. Social structure and competition in interfirm networks: the paradox of embeddedness, Administrative Science Quarterly 42(1), 35-67.

Uzzi, B., Spiro, J., 2005. Collaboration and Creativity: The Small World Problem. American Journal of Sociology 111(2), 447-504.

Watts, D.J., Strogatz, S.H., 1998. Collective dynamics of 'small-world' networks. Nature 393 (6684), 409-410.

Wold, H., 1986. Partial Least Squares, in Kots, S., Johnson, N.L. (Eds.), Encyclopedia of Statistical Sciences (6). John Wiley, New York.

Xiao, Z., Tsui, A.S., 2007. When brokers may not work: the cultural contingency of social capital in chinese high-tech firms. Administrative Science Quarterly 52, March, 1-31.

Zaccaro, S.J., Rittmana, A.L. \& Marksb, M.A., 2001. Team Leadership. The Leadership Quarterly 12(4), 451-483. 


\section{Appendix 1 Sample Characteristics}

Table a Characteristics of respondents' firm $(\mathrm{N}=73)$

\begin{tabular}{lll}
\hline Variables & Number & Percent \\
\hline & & \\
Firm size & & \\
$<20$ employees & 5 & $6.8 \%$ \\
20 to 250 & 12 & $16.4 \%$ \\
250 to 500 & 11 & $15.1 \%$ \\
$>500$ employees & 45 & $61.6 \%$
\end{tabular}

Table b Characteristics of the NPD projects $(N=73)$

\begin{tabular}{|c|c|c|}
\hline Variables & Number & Percent \\
\hline \multicolumn{3}{|c|}{ Project duration (months) } \\
\hline $1-5$ & 8 & $11.0 \%$ \\
\hline $6-11$ & 21 & $28.8 \%$ \\
\hline $12-23$ & 24 & $32.9 \%$ \\
\hline $24-35$ & 10 & $13.7 \%$ \\
\hline $36-48$ & 10 & $13.7 \%$ \\
\hline \multicolumn{3}{|c|}{ Project team size } \\
\hline $1-5$ & 44 & $60.3 \%$ \\
\hline $5-10$ & 18 & $24.7 \%$ \\
\hline $11-67$ & 11 & $15.1 \%$ \\
\hline \multicolumn{3}{|c|}{ Degree of innovation } \\
\hline Very low & 1 & $1.4 \%$ \\
\hline Low & 2 & $2.7 \%$ \\
\hline Quite low & 15 & $20.5 \%$ \\
\hline Quite high & 23 & $31.5 \%$ \\
\hline High & 27 & $37.0 \%$ \\
\hline Very high & 5 & $6.8 \%$ \\
\hline
\end{tabular}


Table c Characteristics of the respondents $(\mathrm{N}=73)$

\begin{tabular}{|c|c|c|}
\hline Variables & Number & Percent \\
\hline \multicolumn{3}{|l|}{ Gender } \\
\hline $\begin{array}{l}\text { Women } \\
\text { Men }\end{array}$ & $\begin{array}{l}12 \\
61\end{array}$ & $\begin{array}{l}16.4 \% \\
83.6 \%\end{array}$ \\
\hline \multicolumn{3}{|c|}{ History with the firm (years) } \\
\hline $\begin{array}{l}1 \text { to } 3 \\
4 \text { to } 5 \\
6 \text { to } 9 \\
10 \text { and more }\end{array}$ & $\begin{array}{l}27 \\
15 \\
15 \\
16\end{array}$ & $\begin{array}{l}37.0 \% \\
20.5 \% \\
20.5 \% \\
21.9 \%\end{array}$ \\
\hline \multicolumn{3}{|c|}{ Educational background } \\
\hline $\begin{array}{l}\text { College degree } \\
\text { Master degree } \\
\text { PhD degree }\end{array}$ & $\begin{array}{l}2 \\
62 \\
9\end{array}$ & $\begin{array}{l}2.7 \% \\
84.9 \% \\
12.3 \%\end{array}$ \\
\hline \multicolumn{3}{|c|}{ Hierarchical level } \\
\hline $\begin{array}{l}\mathrm{N}=\mathrm{CEO} \\
\mathrm{N}-1 \\
\mathrm{~N}-2 \\
\mathrm{~N}-3 \\
\mathrm{~N}-4\end{array}$ & $\begin{array}{l}0 \\
6 \\
26 \\
25 \\
16\end{array}$ & $\begin{array}{l}0.0 \% \\
8.2 \% \\
35.6 \% \\
34.2 \% \\
21.9 \%\end{array}$ \\
\hline
\end{tabular}




\section{Appendix 2 Constructs of latent variables}

\begin{tabular}{|c|c|}
\hline NPD outcomes & \\
\hline \multicolumn{2}{|c|}{ Commercial and financial success } \\
\hline $\begin{array}{l}\text { Griffin and Page } \\
\text { (1993) }\end{array}$ & $\begin{array}{l}\text { Did this project allow your firm to win new markets? } \\
\text { Did this project allow your firm to increase financial returns? } \\
\text { Did this project allow your firm to increase its turnover? }\end{array}$ \\
\hline \multicolumn{2}{|l|}{ Knowledge acquisition } \\
\hline \multirow[t]{3}{*}{$\begin{array}{l}\text { Denison et al. (1996), } \\
\text { Hoegl and } \\
\text { Gemuenden (2001) }\end{array}$} & $\begin{array}{l}\text { Technical knowledge } \\
\text { Did this project allow your firm to obtain new technological competences in } \\
\text { terms of products? }\end{array}$ \\
\hline & Managerial knowledge \\
\hline & $\begin{array}{l}\text { Did this project allow your firm to develop new competences in project } \\
\text { management? } \\
\text { Did this project allow your firm to improve its internal working processes or } \\
\text { methods? }\end{array}$ \\
\hline \multicolumn{2}{|c|}{ Boundary-spanning activities } \\
\hline \multicolumn{2}{|c|}{ During the project, to what extent did you manage to... } \\
\hline \multicolumn{2}{|c|}{ Coordinating with external actors } \\
\hline $\begin{array}{l}\text { Ancona and Caldwell } \\
\text { (1992) }\end{array}$ & $\begin{array}{l}\text { Integrate stakeholders' contributions } \\
\text { Negotiate with stakeholders for delivery deadlines } \\
\text { Review product design with stakeholders } \\
\text { Validate the project's milestones } \\
\text { Transfer information between the project team and the stakeholders }\end{array}$ \\
\hline \multicolumn{2}{|c|}{ Scanning for information } \\
\hline $\begin{array}{l}\text { Faraj and Yan (2009), } \\
\text { Ancona and Caldwell } \\
\text { (1992) }\end{array}$ & $\begin{array}{l}\text { Scan the environment to get information on market trends } \\
\text { Scan the environment to get information on current technological innovations } \\
\text { Consider innovative solutions for problems } \\
\text { Draw from your firm's knowledge stock }\end{array}$ \\
\hline \multicolumn{2}{|c|}{ Obtaining political support } \\
\hline $\begin{array}{l}\text { Faraj and Yan (2009), } \\
\text { Ancona and Caldwell } \\
\text { (1992), Aldrich and } \\
\text { Herker (1977) } \\
\end{array}$ & $\begin{array}{l}\text { Acquire resources from your hierarchy } \\
\text { Persuade your hierarchy to support the team's decisions } \\
\text { Find out whether others in the company support your team's activities }\end{array}$ \\
\hline \multicolumn{2}{|l|}{ Protecting the team } \\
\hline $\begin{array}{l}\text { Faraj and Yan (2009), } \\
\text { Ancona and Caldwell } \\
\text { (1992), Aldrich and } \\
\text { Herker (1977) }\end{array}$ & $\begin{array}{l}\text { Prevent outsiders from "overloading" the team with too much information or too } \\
\text { many requests. } \\
\text { Absorb outside pressures for the team so it can work free of interference }\end{array}$ \\
\hline
\end{tabular}




\section{Appendix 3 Means, Standard deviations, Correlations and AVE}

\begin{tabular}{|c|c|c|c|c|c|c|c|c|c|c|c|c|c|c|c|}
\hline & & 1 & 2 & 3 & 4 & 5 & 6 & 7 & 8 & 9 & 10 & 11 & 12 & 13 & 14 \\
\hline & $\begin{array}{l}\text { Mean } \\
\text { (S.D.) }\end{array}$ & & & & & & & & & & & & & & \\
\hline Coordinating with external actors (1) & $\begin{array}{l}4.410 \\
(0.833)\end{array}$ & 0.760 & & & & & & & & & & & & & \\
\hline Scanning for information and ideas (2) & $\begin{array}{l}4.186 \\
(1.040)\end{array}$ & 0.458 & 0.760 & & & & & & & & & & & & \\
\hline Obtaining political support (3) & $\begin{array}{l}4.454 \\
(1.061)\end{array}$ & 0.464 & 0.404 & 0.749 & & & & & & & & & & & \\
\hline Managerial Knowledge (4) & $\begin{array}{l}4.193 \\
(1.147)\end{array}$ & 0.196 & 0.124 & 0.308 & 0.809 & & & & & & & & & & \\
\hline Protecting the team (5) & $\begin{array}{l}3.763 \\
(1.120)\end{array}$ & 0.237 & 0.054 & 0.177 & -0.036 & 0.906 & & & & & & & & & \\
\hline Horizontal bridging ties (6) & $\begin{array}{l}2.779 \\
(0.578)\end{array}$ & 0.073 & 0.207 & 0.136 & 0.007 & 0.034 & N/A & & & & & & & & \\
\hline Strength of ties (7) & $\begin{array}{l}2.091 \\
(0.394)\end{array}$ & 0.042 & -0.112 & $2-0.154$ & 0.103 & 0.078 & 0.078 & N/A & & & & & & & \\
\hline Structural holes (8) & $\begin{array}{l}0.331 \\
(0.089)\end{array}$ & -0.045 & -0.16 & $7-0.149$ & -0.077 & 0.184 & -0.480 & 0.100 & N/A & & & & & & \\
\hline Technical Knowledge (9) & $\begin{array}{l}4.466 \\
(1.240)\end{array}$ & 0.344 & 0.383 & 0.347 & -0.063 & -0.115 & 0.044 & 0.111 & -0.003 & N/A & & & & & \\
\hline Vertical bridging ties (10) & $\begin{array}{l}0.264 \\
(0.918)\end{array}$ & -0.175 & -0.20 & $4-0.213$ & 0.009 & -0.095 & -0.191 & 0.168 & 0.167 & -0.0261 & $\mathrm{~N} / \mathrm{A}$ & & & & \\
\hline Hierarchical level (11) & $\begin{array}{l}2.342 \\
(0.954)\end{array}$ & 0.304 & 0.167 & 0.241 & 0.079 & 0.092 & 0.357 & -0.161 & $1-0.127$ & 0.086 & -0.707 & N/A & & & \\
\hline Duration of project (12) & $\begin{array}{l}2.531 \\
(0.761)\end{array}$ & -0.106 & 0.027 & 0.049 & -0.092 & $2-0.080$ & 0.149 & -0.023 & $3-0.130$ & 0.001 & 0.021 & -0.0981 & N/A & & \\
\hline Team size (13) & $\begin{array}{l}1.769 \\
(0.730)\end{array}$ & -0.178 & -0.02 & $5-0.070$ & -0.200 & -0.125 & & & 0.063 & & & -0.282( & & N/A & \\
\hline External performance (14) & $\begin{array}{l}3.863 \\
(1.327)\end{array}$ & 0.323 & 0.212 & 0.362 & -0.406 & -0.132 & -0.077 & 0.175 & 0.058 & 0.310 & -0.126 & 0.271 & -0.163 & & 0.805 \\
\hline
\end{tabular}




\section{Appendix 4 Remedies taken against common method bias}

\section{Remedy and Rationale}

Statistical

Harman's one factor test. If a substantial amount of common method bias exists in data, a single or general factor that accounts for most of the variance will emerge when all the variables are entered together (Podsakoff et al., 2003).

\section{Procedural}

To reduce the respondents' tendency to give socially desirable responses and/or to be acquiescent or lenient when crafting their responses we protected respondent anonymity (Podsakoff et al., 2003).

Reducing item ambiguity (Tourangeau et al., 2000)

\section{Implementation}

An unrotated principal factor analysis on all the variables used in the model revealed five factors with eigenvalues greater than 1 which together accounted for $66.8 \%$ of the total variance. The first factor did not account for a majority of the variance $(22.5 \%)$

The introductory web page of our online survey assured complete respondent anonymity.

We pretested the survey which helped us to identify and modify/replace a number of ambiguous questions. 
Figure 1 Conceptual framework

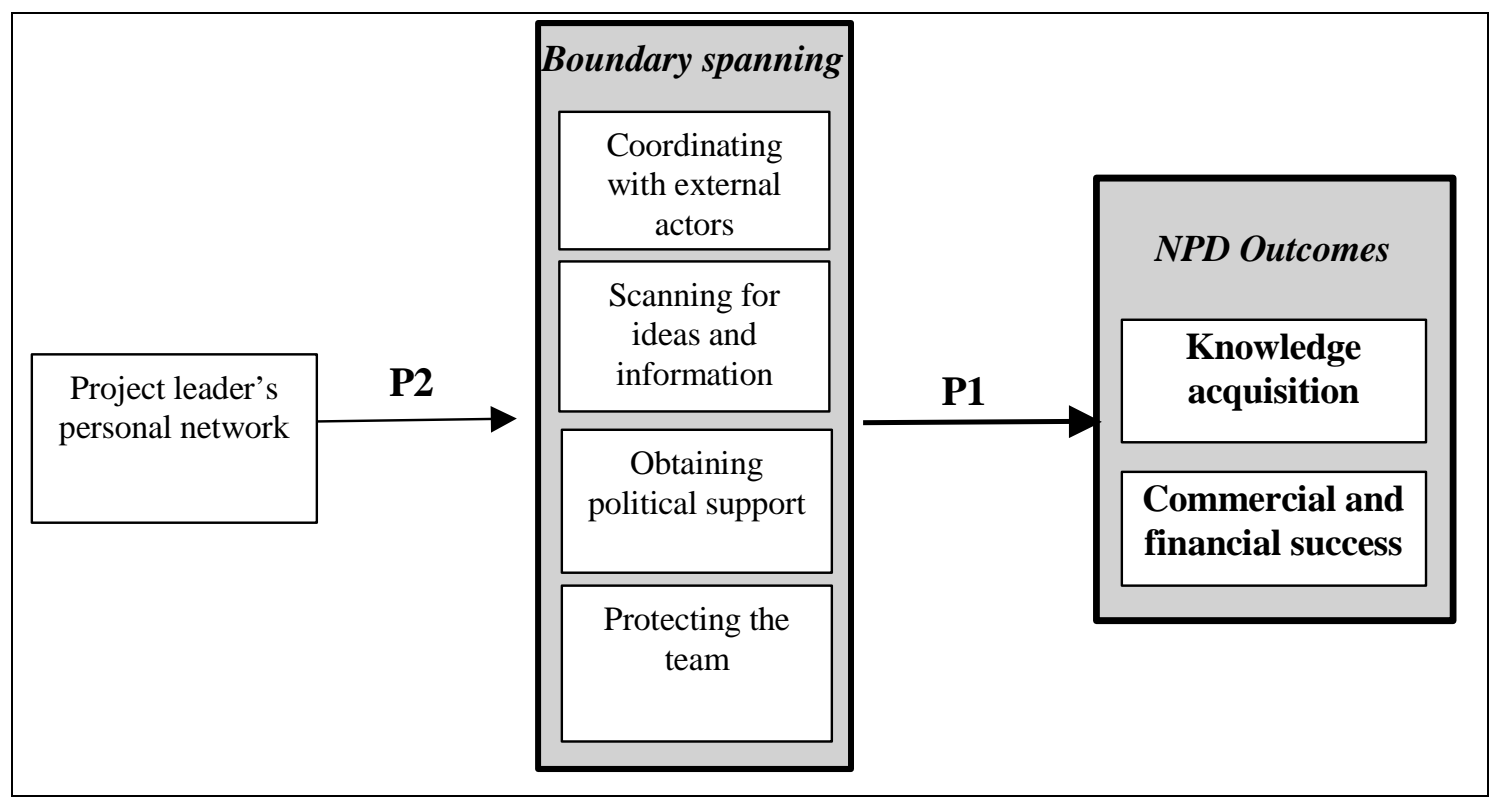


Table 1 Construct reliability, AVE and Alpha

\begin{tabular}{|l|c|c|c|c|}
\hline \multicolumn{1}{|c|}{ Construct } & $\begin{array}{c}\text { Number of } \\
\text { items }\end{array}$ & $\begin{array}{c}\text { Composite } \\
\text { reliability }\end{array}$ & AVE & $\begin{array}{c}\text { Cronbach } \\
\text { Alpha }\end{array}$ \\
\hline Team boundary-spanning activities \\
\hline Coordinating with external actors & 5 & 0.872 & 0.578 & 0.819 \\
\hline Scanning for information and ideas & 4 & 0.845 & 0.578 & 0.758 \\
\hline Obtaining political support & 3 & 0.789 & 0.561 & 0.600 \\
\hline Protecting the team & 2 & 0.901 & 0.820 & 0.786 \\
\hline NPD outcomes & & & & 0.515 \\
\hline Knowledge acquisition & 2 & 0.786 & 0.654 & 0.729 \\
\hline Commercial and financial success & 3 & 0.846 & 0.648 & 0.5 \\
\hline
\end{tabular}


Figure 2 PLS results

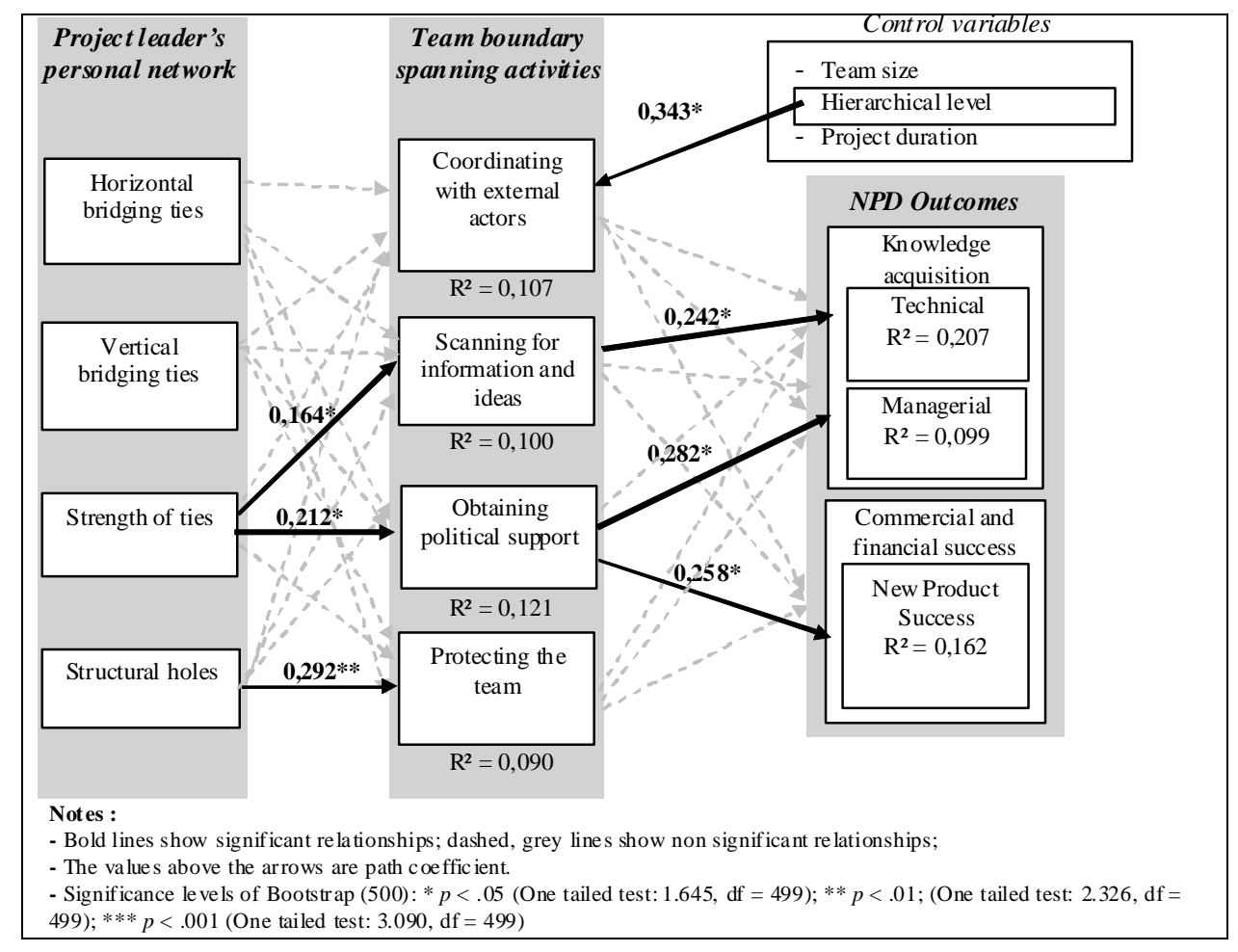




\section{Table 2 Results of mediation tests}

\section{Baron and Kenny (1986)}

Sobel (1988)

\begin{tabular}{|c|c|c|c|c|}
\hline Path & $1^{\text {st }}$ condition & $2^{\text {nd }}$ condition & $3^{\text {rd }}$ condition & Type of mediation $\mathrm{z}$-test \\
\hline$\nearrow^{\mathrm{b}} \searrow_{\mathrm{a}}$ & $\nearrow^{\mathrm{b}}$ & $\mathrm{a} \quad \ldots \ldots \ldots \ldots \rightarrow \mathrm{c}$ & $\bigvee_{\mathrm{a}}$ & \\
\hline$\nearrow_{\text {Strength } \ldots \ldots \ldots . . . .}^{\text {InfoSear }} \searrow_{\text {TechKnow }}$ & $\begin{array}{c}0.210^{*} \\
\text { Validated }\end{array}$ & $\begin{array}{c}0.164 * \\
\text { Validated }\end{array}$ & $\begin{array}{c}0.367 * * * \\
-0.113 \\
\text { Validated }\end{array}$ & Full mediation $\quad p<.05$ \\
\hline$\prod_{\text {Strength }}^{\text {PolitSup }}$ & $\begin{array}{c}0.203^{*} \\
\text { Validated }\end{array}$ & $\begin{array}{c}0.100 \\
\text { Not validated }\end{array}$ & & $\begin{array}{c}\text { No mediation } \\
\text { effect }\end{array}$ \\
\hline$\overbrace{\text { Strength }}^{\text {PolitSup }}$ & $\begin{array}{c}0.203^{*} \\
\text { Validated }\end{array}$ & $\begin{array}{c}0.186^{*} \\
\text { Validated }\end{array}$ & $\begin{array}{c}0.370 * * * \\
-0.129 \\
\text { Validated }\end{array}$ & Full mediation $\quad p<.05$ \\
\hline
\end{tabular}

InfoSear: information scanning; Strength: strength of ties; TechKnow: technical knowledge acquisition;

PolitSup: political support; MgtKnow: managerial knowledge acquisition; ExtPerf: external performance 